\title{
CLIMATIC EFFECTS ON GLACIER DISTRIBUTION ACROSS THE SOUTHERN COAST MOUNTAINS, B.C., CANADA
}

\author{
by
}

Ian S. Evans

(Department of Geography, University of Durham, South Road, Durham DH1 3LE, U.K.)

\section{ABSTRACT}

Over a distance of $150 \mathrm{~km}$ inland across British Columbia, glaciation level (altitudinal threshold for glacier generation) rises north-eastward from $1800 \mathrm{~m}$ near Jervis Inlet, to $2800 \mathrm{~m}$ near Lillooet on Fraser River. The methods of Østrem (1966b) are revised for more detailed work from air photographs; inclusion of small but active glaciers gives a glaciation level some $200 \mathrm{~m}$ below Østrem's from $1: 250000$ maps, or $110 \mathrm{~m}$ below that from $1: 50000$ maps.

Mountains which rise slightly above the altitudinal threshold invariably support glaciers only on their northerly slopes. Mountain crests need to be some $300 \mathrm{~m}$ higher before they support glaciers on most slopes: this defines an "all-sided" glaciation level. Since summit heights vary from 2500 to $2900 \mathrm{~m}$ through most of the transect considered here, east- and west-facing glacier sources are found mainly in the coastal half; south-facing sources are rare outside icefields.

For particular mountain ranges bounded by valleys and low passes, the aspects (azimuths) of glacier sources can be summarised by vector analysis. The higher the range rises above glaciation level, the more widespread the aspects represented and the weaker the resultant vector strength. Strengths as high as $90 \%$ are observed on landward ranges with a relatively sunny, continental climate, while $20-60 \%$ is found for coastal ranges where cloudiness reduces slope variations in incident solar radiation. Vector mean aspects throughout are close to north.

Perennial lee drifts on icefields show that wind directions during and immediately after snowfalls are from the south or from south-south-west. Together with orographic details of the glaciation level, this suggests that snow-bearing winds come from the south rather than the west. These winds reinforce radiation contrasts, giving north-south asymmetry of glacier aspect even near the coast.

\section{INTRODUCTION}

Given a knowledge of climate and topography, and of the relationships between them, a reasonable prediction of mountain glacier balance, and hence of areas generating glaciers, can be made (Gill, 1982). Further empirical data to support and test such models are required. Detailed analyses of the distribution of present glaciers in relation to topography, such as Desio's (1968) work on the Ortles-Cevedale group of Italy, are rare, especially for North America, but important for making more realistic reconstructions of former glaciers (Sutherland, 1984).

In mountains, altitude is the strongest control of mesoclimate, and thus of glacier balance. Hence in studies of single glaciers, it is conventional to plot summer, winter and annual balance against altitude (Østrem, 1966a). On any mid-latitude glacier, balance may be summarised by equilibrium-line altitude (ELA) and balance gradient. For regional studies, the difficulties of averaging snow line or ELA are such that the most convenient concept is glaciation level, the altitudinal threshold for mountains to support glacier generation. This was mapped for the Cordillera north of $49^{\circ} \mathrm{N}$ by $\varnothing$ strem and others (1981), for Washington state by Porter (1977), and related to transient snow line and ELA by Østrem (1973).

The second control of mountain glacier balance is slope aspect, modulated by gradient: this was incorporated into balance studies by Wendler and Ishikawa (1974). Evans (1977) showed how its importance varies regionally, as a function of climate. The "degree of asymmetry" is an important expression of style of mountain glaciation; climate interacts with relief to control this. Relief is regarded as the third control of glacier balance. Local relief and the type of site available for glacier generation are used to explain deviations from a simple pattern of altitude and aspect control.

\section{SOUTHERN COAST MOUNTAINS}

The southern Coast Mountains of British Columbia contain varied relief types (Ryder, 1981) and thousands of glaciers. They were the main source of ice for the Juan de Fuca lobe of the Cordilleran ice sheet. The aim of this study is to account for the distribution of glaciers around $50^{\circ}$ and $51^{\circ} \mathrm{N}$, in a south-west-north-east transect across the Coast Mountains (Fig. 1). This provides a maritime-tocontinental traverse with strong climatic contrasts, comparable to that of southern Norway but some $10^{\circ}$ further south. The north-west-south-east trending mountain ranges interact with Pacific maritime air masses to provide heavy snowfall and high cloudiness near the coast. Proceeding inland, total precipitation during the accumulation season (October-April) declines from $2495 \mathrm{~mm}$ at Woodfibre, $1693 \mathrm{~mm}$ at Squamish and $1407 \mathrm{~mm}$ at Garibaldi, to $837 \mathrm{~mm}$ at Pemberton Meadows, $390 \mathrm{~mm}$ at (lower) Bridge River and $258 \mathrm{~mm}$ at Lillooet (British Columbia, c.1973). All these are valley stations, with annual snowfalls respectively of $147,146,423,282,151$ and $56 \mathrm{~mm}$ water equivalent. Unfortunately, the climatic data available are inadequate for a regression analysis such as that of Porter (1977).

Although the intensity of glaciological work is slight by comparison with that on European mountains, proximity to Vancouver has made this the best-studied part of the Coast Mountains (Young and Ommanney, 1984). This was the first part of the cordillera for which Østrem (1966b) mapped the glaciation level or limit. At the same time, the Geographical Branch began observations on Sentinel Glacier in Garibaldi Park and on Place Glacier north-east of Pemberton (Fig. 1; Østrem, 1966a). These are only $65 \mathrm{~km}$ apart and do not represent the extremes of the traverse, but Letréguilly (1988) has shown that their mass-balance controls are quite different. The relatively maritime Sentinel Glacier (Yarnal, 1984 ) is most sensitive to winter precipitation whereas the more continental balance of Place Glacier is equally affected by summer temperature. More limited series of observations concern Bridge Glacier, and the snout position of Wedgemount Glacier. While the results of single-glacier studies aid the interpretation of glacier distribution, the present study complements these by providing a regional context. 


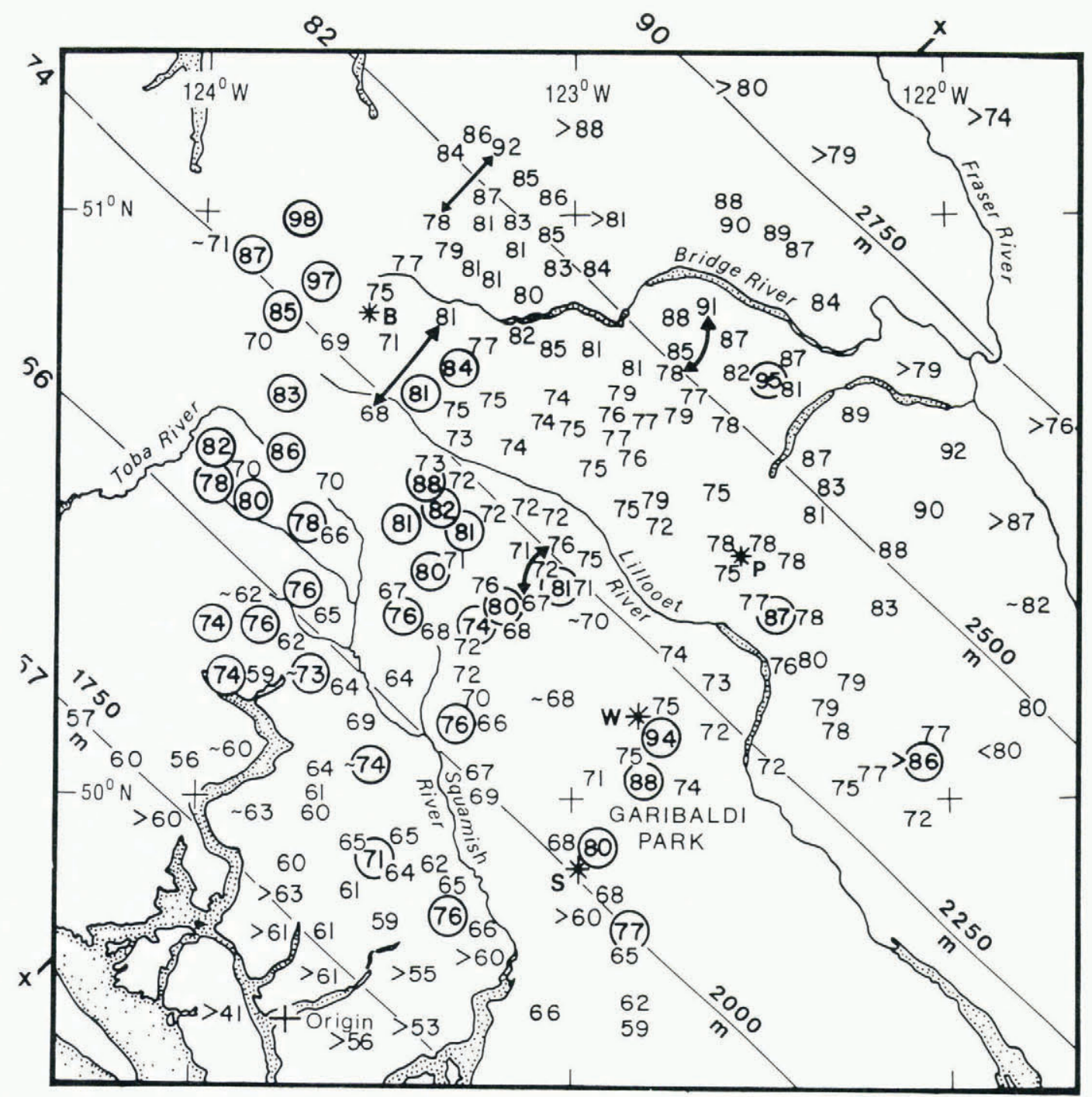

Fig. 1. Mid-20th-century glaciation level in part of the southern Coast Mountains, B.C. (NTS sheet $92 \mathrm{~J}$, north-western $92 \mathrm{G}$ and south-central $92 \mathrm{O} ; 92 \mathrm{~J}$ is $50-51^{\circ} \mathrm{N}, 122-124^{\circ} \mathrm{W}$ ). Plain numbers show altitudinal threshold for mountain crests to support a glacier showing signs of activity; the linear trend surface for these is contoured. Circled numbers show that required to support a glacier on a southerly aspect. Numbers give crest altitude in units of $100 \mathrm{ft}(30.48 \mathrm{~m})$, as on the maps used, rounded down. Glaciers: $\mathrm{B}=$ Bridge; $\mathrm{P}=$ Place; $\mathrm{S}=$ Sentinel; $\mathrm{W}=$ Wedgemount. "Origin" = midpoint of $92 \mathrm{G} 12$, origin of coordinates for the trend surfaces. Double arrows show zones of steepest rise of the glaciation level. $\mathrm{X}-\mathrm{X}=$ line of Figure 2 .

\section{METHODS}

The southern Coast Mountains are not yet covered by the Canadian Glacier Inventory. Cirques and glaciers were mapped across a broad traverse from the coast around Jervis Inlet and Howe Sound to Fraser River by air-photograph interpretation (API) with sample checks in the field.

Photogrammetric 1:50000 maps with $100 \mathrm{ft}(30.48 \mathrm{~m})$ contours are now available for the whole of British Columbia. However, lack of glaciological training among the photogrammetrists meant that many debris-covered ice tongues were omitted while snowbanks outside moraines were included (Henoch, 1969). The results were especially poor for glaciers less than $1 \mathrm{~km}$ long, many of which were omitted. Glaciers 1 to $1.5 \mathrm{~km}$ long were omitted for example near the sources of Mehatl Creek (92J1) and Ryan River (92J6), and in the Elaho basin (92J12 and eastern 92J4). Two small glaciers on northern $92 \mathrm{~J} 5$ were mapped 1.6 to $0.9 \mathrm{~km}$ too short. All these are well crevassed, showing ice and bergschrunds. A few gross errors are corrected in second editions: $1.9 \mathrm{~km}$ long Keary Glacier is added to the 1988 edition of $92 \mathrm{~J} 10$.

Some of these problems may be due to poor timing of the air photography available, inviting confusion between small glaciers and snowbanks. Nevertheless, mistakes of both omission and commission make the 1:50000 and derivative $1: 100000,1: 125000$ and $1: 250000$ maps poor instruments for the study of glacier distribution; hence the need for study of air photographs taken as late as possible in the ablation season.

Fortunately, such photographs are often taken for the BC Forest Service, who permitted me to consult these in their Vancouver office. A total of some 5000 photographs were consulted either there or at the BC Department of Lands and Forests in Victoria. They were at nominal scales mainly between $1: 15000$ and $1: 40000$, taken in September or late August between 1947 and 1978. A further 218 photographs at $1: 63360$ and $1: 31680$ of the Bridge River District in 1947 and 1951 had earlier been provided by the Geographical Branch, Department of Energy, Mines and Resources, Ottawa.

Glacier outlines were drawn on 24 1:50000 map sheets by non-stereo API, aided in some areas by ground photographs. Useful oblique air photographs of the Clowhom-Jervis Inlet area were taken on 2 October 1980. The altitudes (in hundreds of feet, to match the $1: 50000$ contour interval) of crests with and without glaciers were plotted on $1: 250000$ sheet $92 \mathrm{~J}$ and parts of sheets $92 \mathrm{G}$ and 920. Local glaciation levels determined from these maps were plotted at a smaller scale (Fig. 1). 


\section{DEFINITIONS}

With slight modification of Flint (1971, p. 27), a glacier is defined as a perennial, connected mass of ice and firn originating mostly on land from the recrystallization of snow (and refreezing of melt water), and showing evidence of current or former movement (under its own weight). I have used three indicators that a glacier rather than a snowpatch is present on a late-summer air photograph;

(i) Crevasses, the clearest indicator of glacial flow;

(ii) A bergschrund, indicating down-slope movement; on small glaciers bergschrunds are more common than crevasses, but it is just possible that they could occur at the head of large snowpatches, or be confused with avalanche release scars (crowns);

(iii) Glacier ice, shown by a greyer tone than snow and especially clear if several layers differing in shade are visible.

The presence of all three indicators is desirable, but crevasses are the most reliable. Glacier ice alone or surrounded by snow is not sufficient to show contemporary activity. The ice may be a stagnant remnant, though for a small glacier it is likely that it has been active within the last half century. Features which show only ice, with no indication of movement or of strong accumulation (e.g. perennial wind drifts of snow), are excluded here for the definition of a "mid-20th-century glaciation level". Inclusion of ice masses would give the lower "early 20th-century" level. Fresh, almost unvegetated moraines are regarded as late Neoglacial ("Little Ice Age") for small glaciers, although some from large glaciers may have a longer history (Ryder and Thomson, 1986). In some cases the related glacier has wasted away, and it is possible to define a late Neoglacial glaciation level slightly below the 20th-century ones.

Also known as "glaciation threshold" (Porter, 1977), and formerly known as "glaciation limit" (Østrem, 1966b), glaciation level was defined by Østrem and others $(1981$, p. 252$)$ as "a critical minimum summit altitude which is necessary for a mountain to obtain (or maintain) a glacier". I have found it useful to make two small modifications to their topographic qualification of this definition. Though a number of sharp peaks are present in the study area, it has not been necessary to exclude any of them on the grounds that they are too steep to provide adequate space for snow accumulation: usually they provide a deeply shaded concavity suitable at least for a small glacier. Black Tusk (92G14), Mount Currie (92J7) and Mount Sloan (92J15) all support small crevassed glaciers on their steep slopes, though these are omitted from the $1: 50000$ maps.

Working at 1:50000 rather than 1:250000 scale, it is useful to relate glaciers to crests rather than summits. For present purposes, a crest is defined as the high point which influences the site of a possible glacier. It may be a summit, shoulder or gently sloping ridge which is not dominated by higher ground. For the most part, summits are used, but sometimes it may be clear that part of a gently sloping ridge supports a glacier, or could do so, and this provides useful additional information.

\section{GLACIATION LEVEL (THRESHOLD)}

Figure 1 shows the determinations of glaciation level or threshold. Since each determination requires at least one low crest with a glacier, and one high crest without, their spatial pattern is irregular. For some areas, only "greater than" or approximate determinations are available. Most determinations are based on three to five crests; their resolution is $30 \mathrm{~m}$ and they are probably accurate within $60 \mathrm{~m}$. The best determinations are where only one of two neighbouring crests, of equal altitude, supports a small glacier; this is not uncommon. For purely map-based methods Østrem and others $(1981$, p. 255) quoted errors of "up to $150-200 \mathrm{~m}$. The $50 \mathrm{~m}$ quoted by Østrem (1966b, p. 129) related only to repeatability between operators, assuming the maps are perfect.

The overwhelming tendency is for the level to rise from south-west to north-east, from the coast to the interior. This is thought to reflect the diminishing snowfall from Pacific maritime air masses approaching from the south-west (Walker, 1961). Snowfall is associated especially with warm sectors of occluded depressions travelling eastward. These are strongest in winter, but at glaciation level snow can fall in any month.

If unweighted averages of these determinations are taken for each 1:50000 map sheet, covering some $990 \mathrm{~km}^{2}$, the linear trend surface of glaciation level, $G$ (in metres) as a function of eastings, $\mathrm{E}$, and northings, $\mathrm{N}$, in $\mathrm{km}$ from the mid-point of map sheet $92 \mathrm{G} 12$ (grid reference DK 458970, UTM zone 10U: "origin" on Figure 1), is given by

$\mathrm{SEE}=62.8$

$$
G=1676+4.233 \mathrm{E}+4.181 \mathrm{~N} ; \quad R^{2}=0.954, \quad n=27,
$$

or, if sheets with only one or two determinations are excluded, by:

$$
G=1669+4.117 \mathrm{E}+4.247 \mathrm{~N} ; \quad R^{2}=0.952, \quad n=20,
$$

$\mathrm{SEE}=58.2$

If the full data set is augmented by 26 further determinations based on careful reading of maps of 92GNE (at $1: 50000$ and $1: 125000$ ) and of $9203 \mathrm{~W}$, the trend for map sheet averages becomes:

$$
G=1661+4.068 \mathrm{E}+4.347 \mathrm{~N} ; \quad R^{2}=0.947, \quad n=29,
$$
$\operatorname{SEE}=65.6$.

$R^{2}$ values are high partly because of the averaging over map sheets, but they confirm the adequacy and strength of the linear trend; the quadratic has little to add. The standard error (SEE) is only about twice the contour interval used to record the data.

In detail, Figure 1 shows topographic control in the low levels around Jervis Inlet (compared with the Ashlu Creek area to the south-east); and west of Pemberton, where the mountains are exposed to winds from the south, coming up the Cheakamus valley from Howe Sound. Four areas with particularly steep glaciation level rises from south-west to north-east are shown by double-headed arrows on Figure 1. All four extreme gradients relate to mountain ranges which obstruct, and probably divert, air flow from both south-west and south. These local gradients of 25,25 , 17 and $24 \mathrm{~m} \mathrm{~km}^{-1}$ compare with $6 \mathrm{~m} \mathrm{~km}^{-1}$ for the generalized trend surface. They apply over $11-18 \mathrm{~km}$, and clearly could not be sustained over much greater distances. In the Washington Cascades, Porter (1977) obtained gradients of $7-25 \mathrm{~m} \mathrm{~km}^{-1}$, based on averages for $128 \mathrm{~km}^{2}$ map sheets: the other studies which he quotes show gradients mainly between 3 and $15 \mathrm{~m} \mathrm{~km}^{-1}$.

Figure 2 is a generalized section through the Coast Mountains comparing the glaciation level defined by this detailed study with that defined by Østrem (1966b) on the basis of 1:250000 maps (except for 92I4W and I5W, 1:127 000; and 92G14, G13E and J14E, 1:50 000; Falconer and others, 1966). Inspection of map sheet values (Østrem estimated glaciation levels only for 1:50000 whole or half sheets) shows that my values are never higher. Differences range from 0 for sheet $92 \mathrm{I} 5 \mathrm{~W}$ (based on little information) to an outlier of $470 \mathrm{~m}$ for sheet 92J4E (near Jervis Inlet); Østrem has clearly miscalculated on the latter, but the anomalously high value (" $80 "$, or $2440 \mathrm{~m}$ ) is smoothed out in his (Fig. 3) contour map. The median difference is $165 \mathrm{~m}$; the mean excluding $92 \mathrm{~J} 4 \mathrm{E}$ is $163 \mathrm{~m}, 198 \mathrm{~m}$ where Østrem used 1:250000 maps and $108 \mathrm{~m}$ where more detailed maps were used.

Similar differences are expected if the large areas mapped by Østrem and others (1981) are studied in detail. Rather greater lowering of the "glaciation level" will be obtained if all masses of glacier ice are included, regardless of present activity, as most definitions of "glacier" require. Østrem's level might apply to glaciers some $1 \mathrm{~km}$ long, but several glaciers of about this size occur on sheets he excluded in the Bridge River district such as $92 \mathrm{~J} 15,16$ and especially 10 . The overall relationship between map sheet averages may be expressed by the regression equation;

Evans $=-117+0.976$ Østrem, $R^{2}=0.75, \quad \mathrm{SEE}=115 \mathrm{~m}$, $n=21$ for my augmented data set, or

Evans $=-274+1.032$ Østrem, $R^{2}=0.74, \quad$ SEE $=114 \mathrm{~m}$, $n=15$

using only sheets with a number of determinations, based on air-photograph interpretation. It must be emphasised that the differences from Østrem's results are not changes in the distribution of glaciers, but are corrections due to the use of more detailed and more accurate source materials.

How far above ELA is the glaciation level? From 


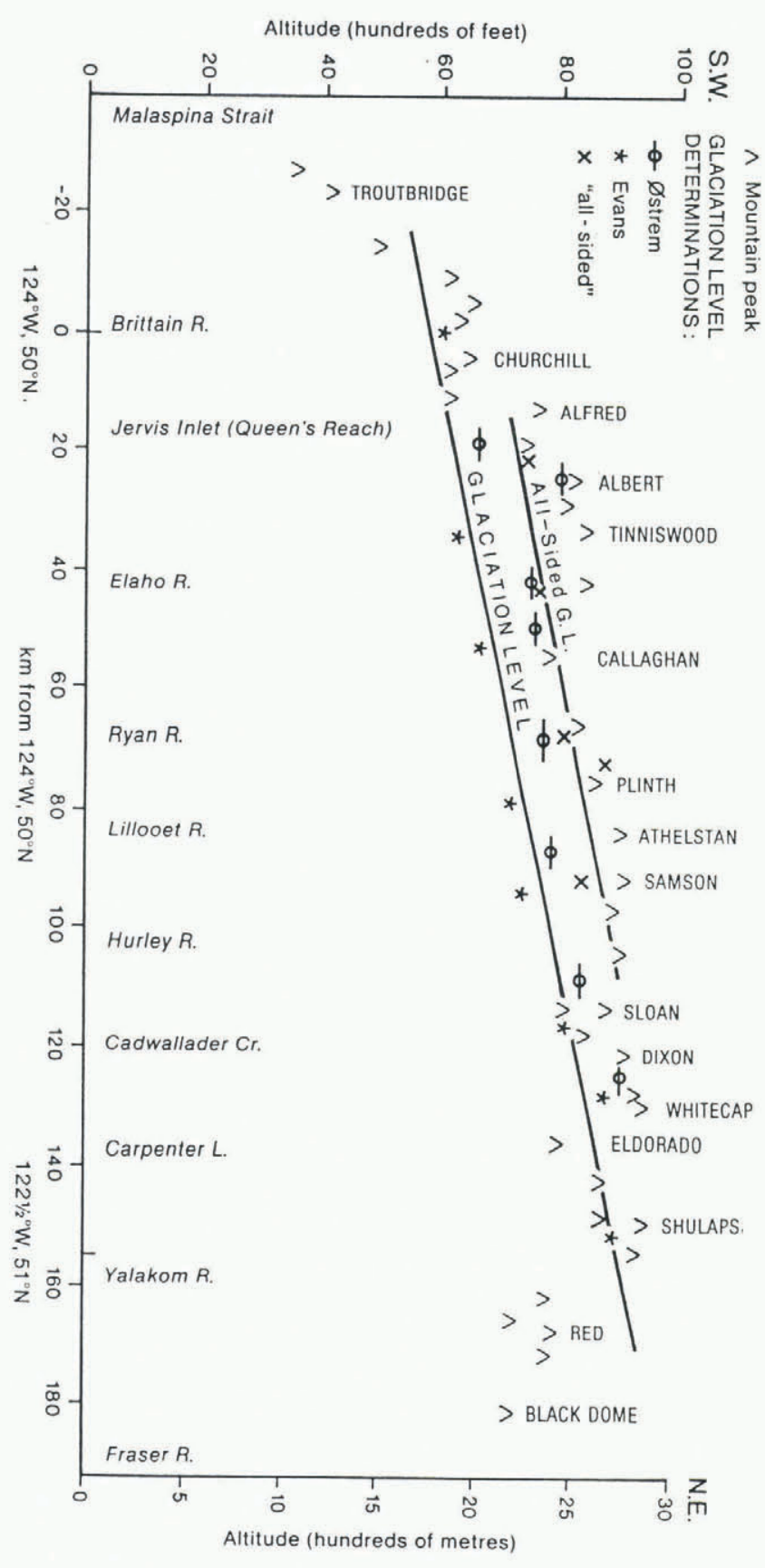

Fig. 2. Transect across the southern Coast Mountains through Jervis Inlet and the Bridge River district $\left(50^{\circ} \mathrm{N}, 124^{\circ} \mathrm{W}\right.$, and $\left.51^{\circ} \mathrm{N}, 122.5^{\circ} \mathrm{W}\right)$, showing glaciation level in relation to highest summits (within $25 \mathrm{~km}$ ) and to Østrem's determinations. The level for "all-sided" glaciation is also shown.

1966-71 mass-balance measurements for Sentinel Glacier (*S on Fig. 1), Østrem (1973) estimated an ELA of $1830 \mathrm{~m}$ to maintain its current extent: he interpolated a glaciation level of $2140 \mathrm{~m}$. However, Sentinel Glacier itself is on Glacier Pikes $(2127 \mathrm{~m})$ : Viking Ridge and Panorama Ridge (to south and north: both $2100 \mathrm{~m}$ ) and perhaps some $2050 \mathrm{~m}$ ridges of Glacier Pikes contribute to glacier accumulation. Mount Price $(2049 \mathrm{~m})$ and The Table $(2019 \mathrm{~m})$ support no glaciers. Hence the local glaciation level is placed at $2070 \mathrm{~m}$ ("68"), $240 \mathrm{~m}$ above the ELA. The glaciation level around Place Glacier ( ${ }^{*} \mathrm{P}$ on Figure 1) is $2350 \mathrm{~m}, 340 \mathrm{~m}$ above the balance ELA of $2010 \mathrm{~m}$. Østrem (1973) gave balance ELAs of 2200,2590 and $2740 \mathrm{~m}$ respectively for Wolsey, Peyto, and Ram River glaciers in the Columbia and Rocky mountains. Corresponding glaciation levels of 2490, 3000 and $3110 \mathrm{~m}$ can be interpolated on Østrem's (1966b) Figure 4. If a correction of $-110 \mathrm{~m}$ is applied (since these are based on 1:50000 maps), the glaciation levels average $250 \mathrm{~m}$ above the three ELAs.

\section{ALL-SIDED GLACIATION}

In the whole of 92JNE, and south to Pemberton, Duffey Lake, and Stein River, there are many glaciers facing north but none facing south, south-west or south-east. The latter are found mainly in the zone of icefields and large glaciers, south-west of the Lillooet River and around its head. Ranges with high relief, as in northern Garibaldi Park, have north-facing glaciers several times as long as south-facing. Where relief is not so great, or has been overwhelmed by glacier growth so that divides are gently-sloping icefields, aspect is much less important Glacier length is then controlled by topographic constraints (especially valley altitude and width) and regional climatic trends. Hence the broad, gentle glaciers flowing south in the icefields at the head of Squamish and Soo rivers are longer and must receive more snowfall than their leeward neighbours feeding Ryan River and South Creek.

The concept of glaciation level can be extended to the generation of southerly-facing (south, south-west, or south-east) glaciers, though there is more local variance due to the difficulty of separating the effects of closely juxtaposed mountains. All crests supporting southerly glaciers also support northerly ones, hence the term "all-sided glaciation". The results, circled on Figure 1, do show a consistent rise to the north-east, comparable to the usual glaciation level but about $300 \mathrm{~m}$ higher throughout. For the Bridge-Lillooet icefields of $92 \mathrm{~J} 13$, however, the difference is anomalously high at some $640 \mathrm{~m}$. This may be because the southerly slopes of nunataks on the icefield may be swept clear by enhanced wind action (see below).

A linear trend surface for all-sided glaciation level, $A$, is $A=2001+3.181 \mathrm{E}+4.792 \mathrm{~N} ; \quad R^{2}=0.772, \quad n=14$, $\mathrm{SEE}=101.7$. This is less well determined than $G$, and the direction of steepest rise is $034^{\circ}$ rather than $043^{\circ}$. Differences between calculated values of $A$ and $G$, at the mid-points of sheets $92 \mathrm{Gl} 16,92 \mathrm{~J} 4$ and $92 \mathrm{~J} 13$, respectively, are 257, 364 and $410 \mathrm{~m}$. Between the Squamish River and the coast the "all- sided glaciation level" is mainly "74" or "76" (around $2300 \mathrm{~m}$ ). In Garibaldi Park it rises steeply from south to north. Around the upper Lillooet River it is about " $85 "(2600 \mathrm{~m})$ and on the northern side of the icefield it seems to rise above "95" $(2900 \mathrm{~m})$. The isolated values in the east are each based on one or two crests and hence not very reliable.

\section{ASPECT ASYMMETRY}

The controls of variations in glacier balance with aspect are mainly (i) differential radiation receipts on slopes; (ii) enhanced deposition of wind-blown snow on sheltered, lee slopes and enhanced ablation on exposed, windward slopes; and (iii) patterns of differential cloudiness between morning and afternoon. These interact with topography to give different distributions of glacier source aspects, summarized by vector analysis for mountain ranges or blocks bounded by valleys and low passes (Evans, 1977).

Table I gives such analyses for selected ranges at the landward and seaward ends and in the centre of the transect. Each data set is a complete population of actual glacier sources, but if it is regarded as a sample of what the relevant processes could produce, each is significantly asymmetric at the 0.05 level. The 84 Bendor "definite" glaciers include those which show glacier ice. Addition of a further 21 remnant and questionable glaciers (possibly snowpatches) does not affect these results, but does lower the glaciation level further.

Glaciation is most marginal in the Bridge River district and this gives the strongest resultants, with only the most favourable aspects generating glaciers. The climate is relatively continental; rock glaciers and ice-cored moraines are common in the Warner and Shulaps-Rex blocks. Resultants are weaker where mountains rise higher above the glaciation level (N. Garibaldi), and near the coast. Reduced asymmetry near the coast is predictable from greater cloudiness, wind exposure and temperature at the glaciation level, increasing the importance of sensible heat flux as compared with radiation (Derbyshire and Evans, 1976). This makes control (i) less important, and control (ii) more important. 
TABLE I. CIRCULAR STATISTICS FOR ASPECT DISTRIBUTIONS OF GLACIER SOURCE AREAS. Aspects were measured mainly to a resolution of $22.5^{\circ}$. Maximum "height" is in hundreds of feet $(30.48 \mathrm{~m})$ above the local glaciation level. Vector summation produces a resultant, giving the mean direction of aspect. Each glacier source is given unit weight: the resultant vector length approaches the total number of sources as the dispersion of aspect declines. Hence length expressed as a proportion of total number, giving resultant vector strength, varies from 0 to $100 \%$ and expresses the degree of asymmetry of glaciation (Evans, 1977). The final column gives an approximation to $95 \%$ confidence limits on the vector mean.

\begin{tabular}{|c|c|c|}
\hline "Height" & Range & $\begin{array}{l}\text { Number of } \\
\text { sources }\end{array}$ \\
\hline
\end{tabular}

Bridge River district (92J 9, 10, 15, 16; 9202 and 3) (Evans, 1974)

\begin{tabular}{|c|c|c|c|c|c|}
\hline 13 & Bendor (all) & 105 & 92 & 87 & $012 \pm 6$ \\
\hline 13 & Bendor (definite) & 84 & 73 & 87 & $011 \pm 6$ \\
\hline 5 & Shulaps and Rex & 26 & 24 & 91 & $011 \pm 10$ \\
\hline 6 & Warner & 66 & 58 & 88 & $010 \pm 7$ \\
\hline
\end{tabular}

Garibaldi-Pemberton (92J2) (Evans, 1974)

$11 \quad$ Carter 11

19 N. Garibaldi

54

7

66

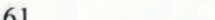

Coastal (92J5 and 4: G14 and 13)

$\begin{array}{llr}23 & \text { Tinniswood-Toba } & 206 \\ 24 & \text { Sims-Jervis } & 47 \\ 13 & \text { Ashlu } & 75 \\ 20(8) & \text { Tantalus-Tzoonie } & 109\end{array}$

$206 \quad 42$

13

21

109

63

21
27
28
58

$359 \pm 35$

$009 \pm 47$

$355 \pm 24$

$013 \pm 12$
What is striking is the consistency of preferred aspects a little east of north, which can be explained purely by radiation effects with a shift due to the time-lag in diurnal heating giving greater temperatures after solar noon; this is common world-wide (Evans, 1977). Though no shift due to wind effects is apparent, the north-north-east tendency is present even near the coast, and is overwhelming in the interior. There appears to be very little structural control of glacier source aspects in the Coast Mountains.

In parts of south-central Alaska, where the glaciation level rises northwards, south winds reinforce radiation effects to give north-facing glaciers and cirques; their distributions are strongly asymmetric (Tuck, 1935). In coastal British Columbia, the glaciation level rises north-eastwards, implying that south-west winds are the main bearers of snow. This, however, may be misleading, as wind-drift features seem to show. Whether winds come from west, south or anywhere between, the glaciation level is likely to rise with distance into the mountains, i.e. to the north-east.

\section{WIND AND SNOW}

It is futile to relate mountain climates to wind directions measured in valleys, since the wind generally blows either up-valley or down-valley. Very few wind observations are available on mountains in British Columbia. The glaciers themselves, by integrating the effects of several climatic variables over decades, are the best indicators we have of climate in the mountains. In addition to their distributions over altitude and aspect, discussed above, they provide indications of wind drift direction.

On the icefields of the west, accumulation area gradients are relatively gentle. Summits and nunataks interfere with the pattern of drifting, producing linear lee drifts commonly a few hundred $\mathrm{m}$ long but occasionally over $1 \mathrm{~km}$. They form by wind-blown snow accumulating in relatively sheltered locations (the drift extends the zone of shelter) during and soon after snowfall; later, snow is usually too compacted or crusted to be blown. These aeolian features are considered to be perennial because of their size, because they are seen on late-summer photographs and have thus survived (most of) the ablation season, and because they are consistent in photographs from different years. Many that are tens of $\mathrm{m}$ high are too large to be much displaced by a single snowstorm.

In snow as in sand, lee drifts are the best indicators of net resultant drift, i.e. of wind direction during and soon after snowfalls or sandstorms. Windward scoops (cf those between obstacles and echo dunes) reinforce this evidence, but are directionally less precise. On steeper ridges snow drifts are shorter and more closely spaced, but in areas of marginal glaciation drifts are rarely present because glaciers are sheltered below cliffs, in deep concavities.

Hence Figure 3 gives the dominant wind directions shown by major lee drifts in the western half of the study area (there are few in the east). A surprising number show flow from the south or south-south-west. Southwesterlies dominate around the Bridge and Lord icefields, and both north-west and east of Elaho Glacier. These seem to show deflection of the dominant northward flow, perhaps on regionally leeward slopes. Alternatively they may reflect channelling of air flow north-eastward up the Toba valley to the Bishop: Lillooet divide or up Jervis Inlet into the Elaho valley. Drifts toward $030^{\circ}$ are rare: the principal mode is $0-020^{\circ}$, the secondary one $040^{\circ}$.

The median of the 135 observations mapped (most of which consist of several lee drifts) is toward $010^{\circ}$. This is oblique to the trend of rising glaciation levels, but close to the mean aspect of glacier sources. Hence the strength of asymmetry in the southern Coast Mountains, and its persistence toward the coast, may be due to wind effects reinforcing solar radiation effects. Here, leeward slopes and shady slopes are the same. The orographic effects on glaciation level, noted above, also imply winds funnelled northwards up major valleys which are relatively straight.

\section{CONCLUSIONS}

The concept of "glaciation level" is extended here to define an "all-sided" glaciation level. Though not a good indicator of wind direction, glaciation level is very flexible in that it can be a useful tool for analysing the altitude control of different sorts of glacier, and indeed of glacial cirques. Detailed API produces a level some $198 \mathrm{~m}$ below that defined by Østrem from 1:250000 maps. The revision 


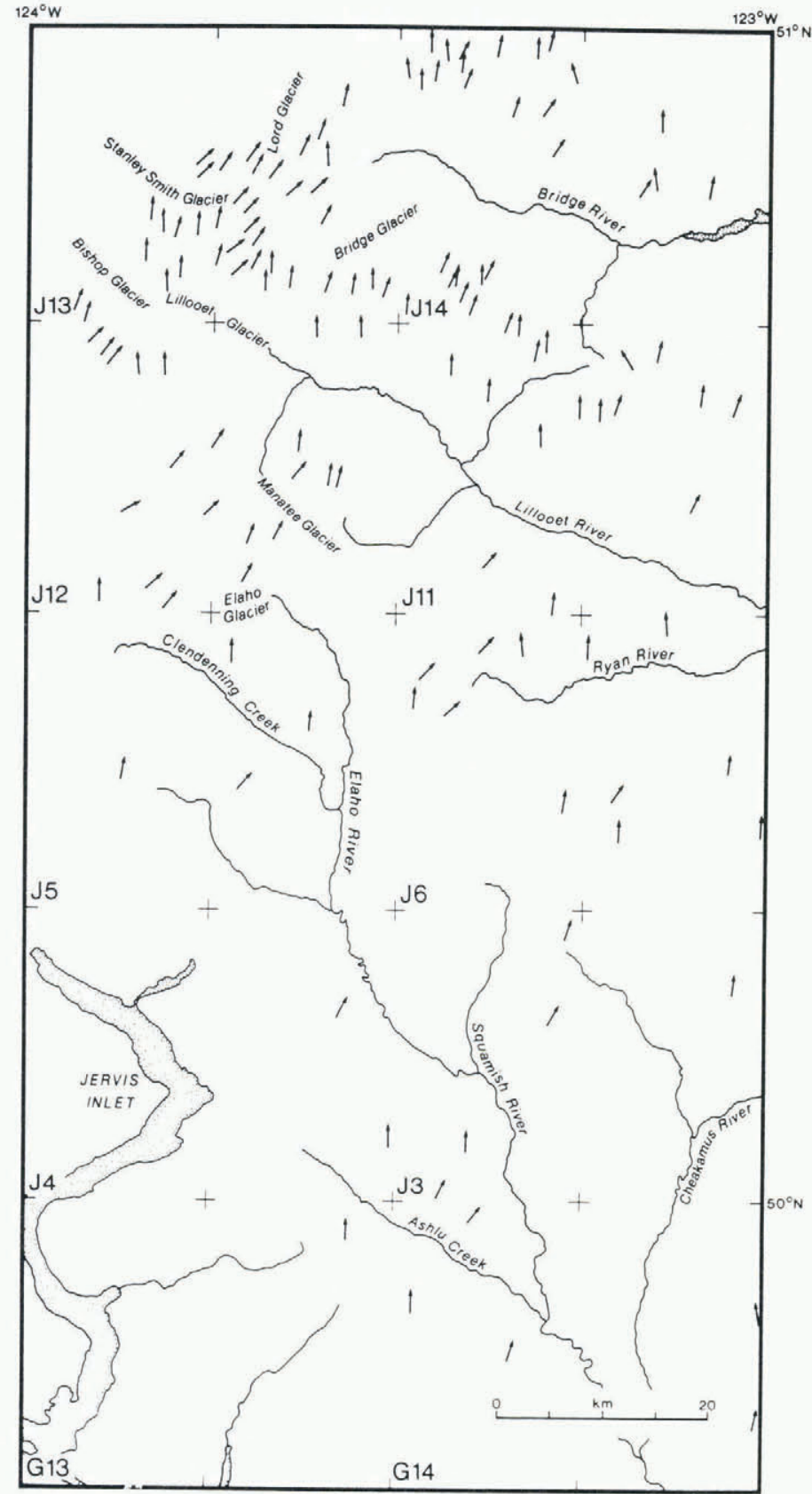

Fig. 3. Perennial aeolian drift features in snow on icefields and glacier accumulation areas in the west half of 92J and north-west part of $92 \mathrm{G}$. These are believed to reflect the locally dominant surface wind direction during snow accumulation. 1:50000 NTS map numbers within 92 are given in the south-west corner of each sheet.

of glacial outlines on 1:50000 topographic maps is necessary if glaciers around $1 \mathrm{~km}$ long and smaller are to be studied, but API is very labour-intensive and the work summarized in Østrem, and others (1981) is unlikely to be replaced in the near future. The differences found here can serve as first-order corrections to Østrem's glaciation levels within Canada.

Glacier distributions, and aeolian drifts in snowfields, are the best indications we have of surface climatic conditions in the mountains. Only a few glaciers can be selected for mass-balance studies; the selection is purposive (Østrem, 1966a), and the results should be interpreted in relation to the broader regional patterns of glaciation.

The BC Coast Mountains show steep gradients in precipitation and in snowfall, from coastal rain forest to sagebrush scrub, and this is associated with a $1000 \mathrm{~m}$ rise in glaciation level over $150 \mathrm{~km}$. Near the coast, mass balance is controlled by whether snowfall is heavy or very heavy. In the interior, summer temperatures (controlled by duration of clear skies) are more important for inter-annual variations in balance; asymmetry of glaciation is very strong. Snow-bearing winds come from a more southerly direction than the general trend of glaciation level implies.

\section{ACKNOWLEDGEMENTS}

I am grateful to Durham University for research leave and funds for work in British Columbia, to G. Østrem, J.D. Ives, W.H. Mathews, and A.L. Washburn for their help during earlier stages of this work, and to the University of British Columbia, the British Columbia Forest Service and Department of Lands and Forests for their cooperation. Useful comments on the paper were received from N.J. Cox, C.S.L. Ommanney, R.B. Sagar and the referees. The paper was typed by E. Pearson, and the figures drawn by $D$. Hume.

This paper is dedicated to the memory of Brian Sagar (1927-1990) glaciologist and geographer, of Simon Fraser University.

\section{REFERENCES}

British Columbia. Department of Agriculture. c.1973. Climate of B.C.; climatic normals 1941-70. Victoria, B.C., Queen's Printer.

Derbyshire, E. and I.S. Evans. 1976. The climatic factor in cirque variation. In Derbyshire, E., ed. Geomorphology and climate. New York and London, J. Wiley and Sons, 447-494.

Desio, A. 1968. I ghiacciai del gruppo Ortles-Cevedale (Alpi Centrali). Torino, Comitato Glaciologico Italiano.

Evans, I.S. 1977. World-wide variations in the direction and concentration of cirque and glacier aspects. Geogr. Ann., 59A(3-4), 151-175.

Evans, I.S. Unpublished. The geomorphometry and asymmetry of glaciated mountains. (Ph.D. thesis, University of Cambridge, 1974.)

Falconer, G., W.E.S. Henoch, and G.M. Østrem. 1966. A glacier map of southern British Columbia and Alberta Geogr. Bull., 8(1), 108-112.

Flint, R.F. 1971. Glacial and Quaternary geology. New York and London, J. Wiley and Sons.

Gill, J.S. Unpublished. Simulation of cirque glacier distribution. (Ph.D. thesis, University of Durham, 1982.)

Henoch, W.E.S. 1969. Topographic maps of Canada in glaciological research. Can. Cartogr., 6(2), 118-132.

Letréguilly, A. 1988. Relation between the mass balance of western Canadian mountain glaciers and meteorological data. J. Glaciol., 34(116), 11-18.

Østrem, G. 1966a. Mass balance studies on glaciers in western Canada. Geogr. Bull., 8(1), 81-107.

Østrem, G. 1966b. The height of the glaciation limit in southern British Columbia and Alberta. Geogr. Ann., 48A(3), 126-138.

Østrem, G. 1973. The transient snowline and glacier mass balance in southern British Columbia and Alberta, Canada. Geogr. Ann., 55A(2), 93-106.

Østrem, G., N. Haakensen, and T. Eriksson. 1981. The glaciation level in southern Alaska. Geogr. Ann., 63A(3-4), 251-260.

Porter, S.C. 1977. Present and past glaciation threshold in the Cascade Range, Washington, U.S.A.: topographic and climatic controls, and paleoclimatic implications. $J$. Glaciol., 18(78), 101-116.

Ryder, J.M. 1981. Geomorphology of the southern part of the Coast Mountains in British Columbia. Z. Geomorphol., N.F., Supplementband, 37, 120-147.

Ryder, J.M. and B. Thomson. 1986. Neoglaciation in the southern Coast Mountains of British Columbia. Can. J. Earth Sci., 23, 273-287.

Sutherland, D.G. 1984. Modern glacier characteristics as a basis for inferring former climates with particular reference to the Loch Lomond stadial. Quat. Sci. Rev., 3, 291-309.

Tuck, R. 1935. Asymmetrical topography in high latitudes resulting from alpine glacial erosion. J. Geol., 43, $530-538$. 
Walker, E.R. 1961. A synoptic climatology for parts of the Western Cordillera. Montreal, McGill University. (Publications in Meteorology 35.)

Wendler, G. and N. Ishikawa. 1974. The effect of slope, exposure and mountain screening on the solar radiation of McCall Glacier, Alaska. J. Glaciol., 13(68), 213-226.

Yarnal, B. 1984. Relationships between synoptic-scale atmospheric circulation and glacier mass balance in south-western Canada during the International Hydrological Decade, 1965-74. J. Glaciol., 30(105), 188-198.

Young, G.J. and C.S.L. Ommanney. 1984. Canadian glacier hydrology and mass balance studies; a history of accomplishments and recommendations for future work. Geogr. Ann., 66A(3), 169-182. 